\title{
Research on the Influence Factors of Post-grouting Bored Piles Load-bearing Capacity
}

\author{
Jianbin GAO \\ Henan Province Highway Engineering Bureau Group co. Ltd \\ Zhengzhou, China \\ e-mail: 512041516@qq.com
}

\section{Gaojie REN}

School of Water Conservancy \& Environment Eng ineering Zhengzhou University

Zhengzhou, China

e-mail: gaojie-ren@qq.com

\author{
Yunxia LIU \\ Henan Province Highway Engineering Bureau Group co. Ltd, \\ Zhengzhou, China \\ e-mail: 495589964@qq.com \\ Qingfu LI \\ School of Water Conservancy \& Environment Engineering \\ Zhengzhou University \\ Zhengzhou, China \\ e-mail: lqflch@zzu.edu.cn
}

\begin{abstract}
Numerical model of post-grouting bored piles which are applied to specific engineering was built and analyzed, the result of numerical model was compared with the static test result of test piles on site, which confirmed the feasibility and rationality of the numerical model. By the numerical model, the influence factors of post-grouting bored piles used by a cable-stayed bridge under construction was analyzed, the result show that: (1) the bearing capacity of bored - pile could be improved through the post-grouting technology; (2) the Elastic Modulus of the solidified body is proportional to the bearing capacity of bored - pile, however there exists an optimum Elastic Modulus value; (3) the bearing capacity of bored - pile was affected heavily by the penetrating depth of the grout, there exists a reasonable range of grouting quality and grouting pressure.
\end{abstract}

Keywords-post-grouting piles; static test; finite element analysis

\section{INTRODUCTION}

The post grouting technology of bored pile is an improved construction technology based on ordinary bored piles, which can effectively improve the bearing capacity of pile foundation, so it is widely used in high-rise buildings, large bridge pile foundation construction [1]. Post grouting technology can be classified into three types: pile-bottom post grouting technology, pile-side post grouting technology and pile-bottom\& pile-side joint post grouting. Among these, pile-bottompost grouting technology is the simplest one and could improve the bearing capacity of piles dramatically, so it is applied widely. Pile-bottom post grouting technology is such a technology: certain mixed seriflux is pressed in the boring hole. Bored Piles bottom post grouting is a method in which solidified cement slurry is injected into the bottom area of the pile through grouting pipes after the strength of the concrete reaches a certain value to strengthen the loose sediment at the holes base and the soil around the pile [2-3] Bored side post grouting is similar with it and the routing pipes are reserved around the pile side. The mechanics function machine of bored pile post-grouting technology could be classified mainly into four types: function of consolidation, function of gumming, function of filling \& compaction and function of splitting \& stiffening $[4,5]$.

A large number of experimental studies have been carried out on the post grouting bored pile: Different grouting modes and grouting amount were studied on the test piles in the construction of Xinxiang-Zhengzhou Yellow River Bridge [6]. The production process of the post grouting technology of super-long piles was introduced and the test pile experiment was conducted by Ke Hong based on a Tianjin high-rise building foundation, the research results show that post-grouting technology could improve the bearing capacity of bored pile but the improvement value of bearing capacity is uncertain [7]. 186 test piles were investigated from 72 construction sites by Hu Chunlin [8]; the possibility that the ultimate bearing capacity of bored piles was improved $54.67 \%$ is very large according to the survey results. However the conclusion that the bearing capacity could be improved several times is rigorous according to the survey result conducted by Zeng Wentao [9], because the test result may be affected by geological conditions, grouting quantity, pile parameters, and many other factors. Based on the same or similar geological conditions, the main influence factors of bearing capacity of bored was analyzed by 3-D finite element numerical analysis software to optimize the post grouting technology. 
TABLE I. The MechanicAl CHARACTERISTICS AND PARAMETER OF EVERy Floor

\begin{tabular}{|c|c|c|c|c|c|c|c|}
\hline Floor & Name & $\begin{array}{c}\text { Thickness } \\
{[\mathrm{m}]}\end{array}$ & $\begin{array}{c}\text { Unit Weight } \\
{\left[\mathrm{kN} \cdot \mathrm{m}^{-3}\right]}\end{array}$ & Void Ratio & $\begin{array}{c}\text { Cohesion } \\
{[\mathrm{kPa}]}\end{array}$ & $\begin{array}{c}\text { Internal Friction } \\
{\left[{ }^{\circ}\right]}\end{array}$ & $\begin{array}{l}\mathrm{MOE} \\
{[\mathrm{Mpa}]}\end{array}$ \\
\hline 1 & Earth fill & $37 \sim 5.0$ & & & & & \\
\hline 2 & Silty Clay & $5.5 \sim 8.1$ & 18.3 & 1.014 & 8 & 19.50 & 4.54 \\
\hline 3 & Mucky Clay & $3.6 \sim 7.3$ & 17.71 & 1.371 & 9 & 8.75 & 2.17 \\
\hline 4 & Clay & $2.6 \sim 6.5$ & 17.71 & 1.187 & 10 & 9.00 & 2.48 \\
\hline 5 & Silty Clay & $22.0 \sim 24.0$ & 18.3 & 0.981 & 11 & 15.00 & 4.15 \\
\hline 6 & Silty Clay & $1.8 \sim 3.3$ & 20.0 & 0.646 & 33 & 15.00 & 6.10 \\
\hline 7 & Sandy Silt, Silty Sand & $17 \sim 4.7$ & 19.3 & 0.739 & 3 & 27.50 & 15.39 \\
\hline 8 & Silty Clay & Not drill Out & 18.3 & 1.014 & 19 & 14.0 & 5.88 \\
\hline
\end{tabular}

\section{NUMERICAL MODELING AND VALIDATION}

\section{A. Project Profile}

The construction technology of bored pile was used in a high-rise building foundation in Shanghai, and the static load test was carried out before and after the grouting of pile 94 . The settlement displacement of pile top was recorded during the loading process. The length of test pile is $37.7 \mathrm{~m}$, the diameter is $0.6 \mathrm{~m}$. According to the geological exploration, $50 \mathrm{~m}$ depth of the ground soil of the foundation is the quaternary unconsolidated sediments, specific formation physical parameters are shown in table 1 [10]. The loading is divided into two groups: the first group (before grouting) and the second group (after grouting). According to the "Building Foundation Design Specification", Each loading is conducted step by step, every step loading is not less than 2 times of the design capacity in each group, and each group loading is divided not to be less than 8 steps; After each step loading, next level of load could be applied if the settlement is below $0.1 \mathrm{~mm}$ in continuous two hours. The loading should be terminated when the soil around the bearing plate is squeezed out obviously of the side of the side extrusion or the settlement increased rapidly or the settlement rate could not reach a stable value within 24 hours. The Q-S curve is plotted according the test.

\section{B. Numerical Modeling}

As the engineering geology condition is complex, some hypotheses are made as follows to make numerical model: (1) pile body was linear elastic material; (2) the foundation soil was plasticity continuum, which follows the Mohr-Coulomb theory; (3) after entering into the foundation soil, the paste and the soil became solidified body, which was cylindrical; (4) there was friction between the pile body and the soil around the pile, however there were no skidding between them; (5) the stress and displacement variations of the soil caused by the bored pile construction was not be considered. Based general FEM software ANSYS, the numerical model was built, whose parameter were selected as follows: the depth of the foundation is twice the length of the pile; the horizontal width and length of the foundation is ten times the diameter of the pile. The material factors of the pile and solidified body was shown in table 1 . The pile, solidified body and soil are all simulated by the element with 8 nodes. The soil is simulated by DP material model. The contact surface between is summited by TARGET 170 and TARGET 173 . Considering the symmetry of the model, half of the model was built only. The final model was shown in figure 1.

TABLE II. THE MATERIAL FACTORS OF THE PILE AND SOLIDIFIEd Body

\begin{tabular}{|c|c|c|c|c|}
\hline Maerial & Unit Weight $\left[\mathrm{kN} \cdot \mathrm{m}^{-3}\right]$ & Elastic Modular [Mpa] & Poisson Ratio & Failure Criterion \\
\hline Pile & 25.0 & 30000 & 0.2 & Linear Elasticity \\
\hline Solidified Body & 20.0 & 15000 & 0.2 & Linear Elasticity \\
\hline
\end{tabular}




\section{NUMERICAL MODEL TEST}

The numerical model can simulate the bearing capacity of the pile foundation, however the selection of model parameter, the hypothesis of the model and other factors are able to affect the result of the model. To test the correctness of the model, the result of model and the static load test of the pile in site were compered in figure 2 . The result shown that: no matter post grouting bored pile or ordinary pile, the displacement of pile tip in the numerical model is not much different from that coming from the static load test of the pile in site, the maximal error is $2.48 \mathrm{~mm}$; The Q-S graph coming from numerical model basically agrees with that from test in site, Simulating the carrying capacity of post grouting bored pile by numerical model is feasible [11].

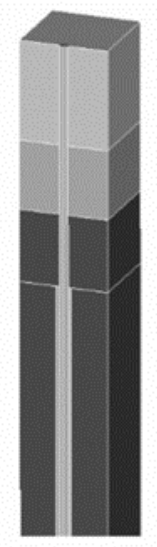

Figure 1. The numerical model

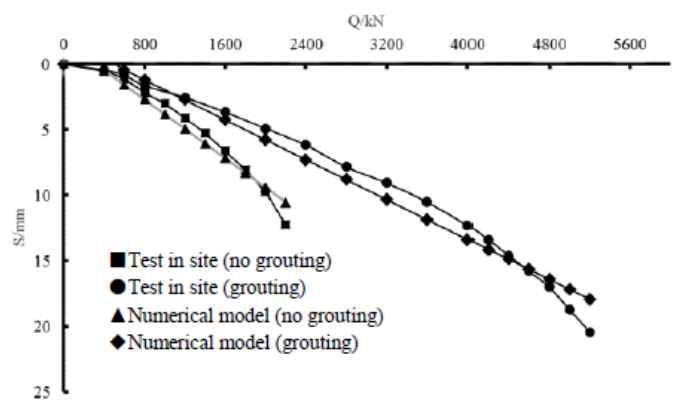

Figure 2. The comparison result between numerical model and test in site

\section{RESEARCH ON THE INFLUENCE FACTORS OF POST-GROUTING BORED PILES LOAD-BEARING CAPACITY}

\section{A. The General Information on the Project}

The end-side grouting technology was applied in the bored pile group foundation of Shangdeng Highway Bridge. The pile diameter is $2.0 \mathrm{~m}$. There are two kinds of pile length, which are $93.0 \mathrm{~m}$ and $95.0 \mathrm{~m}$. The pile foundation belongs to long-large diameter bored pile. According to the geological prospecting, friction piles were used in Shangdeng Highway Bridge. Based on this engineer, the finite element models of the pile foundation were built to analyze the influence factors of the bearing capacity of the post grouting piles.

\section{B. The Influence of the MOE of Solidified Body on the Bearing Capacity of Bored Piles}

To analyze the influence of the MOE of solidified body on the bearing capacity of bored piles, the depth of cement grout permeation was as sumed to be $0.5 \mathrm{~m}$. The MOE of the solidified body was assumed to be twice, four times, eight times, ten times of the compression modulus of first floor soil. The Q-S graph of pile in different MOE of solidified was shown in figure 3. The result shown that: (1) Under the loading of $400 \mathrm{KN}$, the pile-top displacements of pile-bottom post grouting pile and common bored pile are not much different, because the loader is smaller, the fiction around the pile is much smaller than the ultimate capacity, the solidified body has not play a role in bearing loading; (2) under the same loading of more than $2400 \mathrm{KN}$, the displacement of pile-bottom post grouting pile is much smaller than that of common bored pile and the difference increase with the MOE of the solidified, hereinto under the loading of $500 \mathrm{KN}$, where the MOE of solidified is $10 \mathrm{Es}$, the relative decrease of displacement of the pile tip is $10.63 \%$; (3) when the MOE reaches $8 \mathrm{Es}$, the bearing capacity of post grouting does not increase with the MOE.

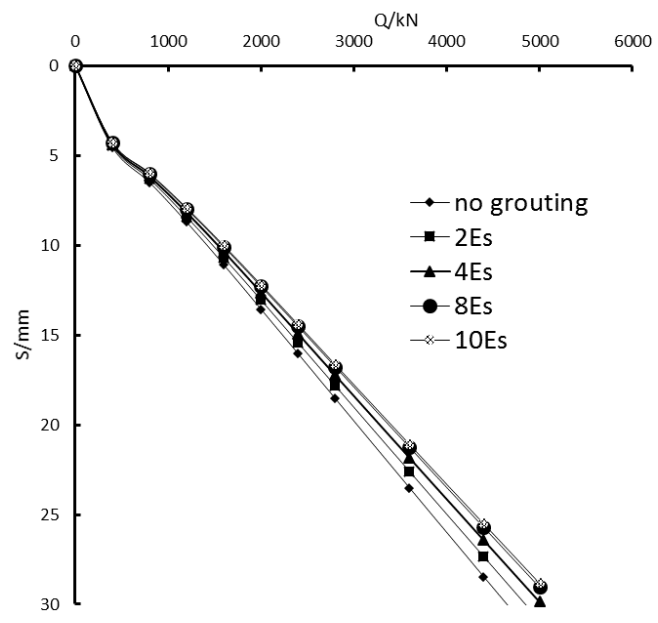

Figure 3. Comparison Q-S under different MOE of solidified

\section{Influence of Pile-bottom Grouting Amount on the Bearing Capacity of Bored Pile}

The MOE of the solidified was assumed to be five times that of firs floor soil, the depth of cement grout penetrating soil was set as $0.5 \mathrm{~m}, 1.0 \mathrm{~m}, 1.5 \mathrm{~m}, 2.0 \mathrm{~m}$, the Q-S graph under different depth of penetration could be got, which was shown in figure 4, it shown that: (1) The bearing capacity of bored pile was improved by pile-bottom post grouting technology and also the bearing capacity increased with the depth of generation. For example, while the MOE of the solidified was 5Es and the depth of cement grout penetrating soil increase from 0.5 to $2.0 \mathrm{~m}$, under the loading of $5000 \mathrm{KN}$, the displacement of the bored pile are $10.11 \%, 15.06 \%, 17.12 \%, 18.43 \%$, comparing with the common bored pile. (2) There was a reasonable grouting amount in the pile-bottompost grouting technology. 
It was shown in figure 4 that the decrement of displacement decreases with depth of cement grout increasing. For example, while the MOE of solidified was 5Es and the depth of cement grout penetrating soil increase from $0.5 \mathrm{~m}$ to 2.0 , under the loading of $500 \mathrm{KN}$, the relative decrement of placement of pile tip were $5.446 \%, 2.49 \%, 1.57 \%$. The summary under this condition indicates that under the construction and design of pile-bottom post grouting bored pile, the particular case of engineering geology should be taken consideration to ensure that the grout amount and pressure are kept within reasonable range, which can make full use of the bearing capacity of post grouting pile and also save the cost of construction.

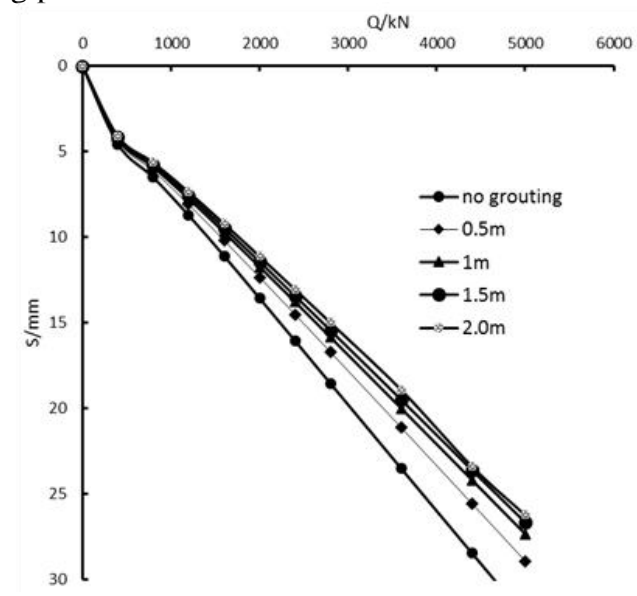

Figure 4. Comparison Q-S under different depth of cement grout penetration

\section{CONCLUSION}

The research result shows that: (1) it has sustainability to simulate the post grouting bored pile by 3 -d finite element software to analyze its bearing capacity. Numerical methods could be taken into consideration to evaluate the bearing capacity of bored pile when there is no pile test condition in site. (2) The MOE of solidified body has a significant effect on the bearing of post grout bored pile, which has a positive correlation with the bearing capacity and there is a reasonable value of MOE. (3) The bearing capacity of post grouting bored pile increases with depth of cement grout penetration. The grout pressure and amount should be controlled in the construction. There is a critical value of penetration depth; the improvement of bearing capacity will not increase obviously if the depth of cement grout penetration is larger than this value. (4) Post grouting technology includes pile-bottom post grouting, pile-side post grouting and post grouting at pile bottom and side. This paper just researched on the influence factors of pile-bottom post grouting bored pile. Further researcher need to see the influence of pile-side post grouting and post grouting at pile bottom and side on the bearing capacity of bored pile.

\section{REFERENCES}

[1] Wu Yonghong, Li Wenchun, Weng Yongnina. The Advance and Some Problems of Pile Foundation [J]. Geotechnical Engineering Technique, Vol.18 (4), p.163-167, 183. (2014)

[2] Bruce, D A. Enhancing the Performance of Large Diameter Piles by Grouting [J]. Grouting Engineering, Vol.19 (4), p.9-15. (1986)

[3] Wang Xiuzhe, Gong Yueming et al. Current Research Status and Development of the Pile-end Post-grouting Technology [J]. Construction Technology, Vol. 33(5), P.28-31. (2004)

[4] Huang Shenggen, Zhang Xiaowei, Cao Hui. Mechanism Study on Bored Cast-in-place Piles with Post-Grouting Technology. Rock and Soil Mechanics. Vol.25 (2), P.251-254. 2004.

[5] Deng Xianghui, Zhang Yongjie, Fang Haibo. Bearing Capacity Analysis and Experiment Research on Post-grouting Bored Piles. Journal of Architect ure and Civil Engineering .Vol. 32(2), P.58-64. (2015)

[6] Huang Gensheng, Wang Hui, Zhang Xiaowei et al. Study on the Grouting Effects of Super Long Large Diameter Bridge Piles. Journal of Highway and Transportation Research and Development. Vol.21 (5), P.73-76. (2004)

[7] Ke Hong, Zhao Chunhong et al. Pile Testing Process of Large Diameter and Super Long Bored Pile with Post Grouting Tech nique. Construction Technology. Vol. 44(7), P.95-97, 103. (2015)

[8] Hu Chunlin, Li Xiangdong et al. Study of Vertical Bearing Capacity for Post-grouting Bored Pile. Chinese Journal of Rock Mechanics and Engineering. Vol.20 (4), P.546-550. (2001)

[9] Zeng Wentao. Bearing Capacity Trial Study of Single Stake Limitation of Post Motar Pouring. Journal of Hunan City University Natural Science. Vol. 20(2), P.10-13. (2011)

[10] Zhao Zhenyun, Zhou Hongbo. Analysis and Numerical Simulation on the Bearing Capacity of Post-grouting Bored Pile. Journal of Highway and Transportation Research and Development. Vol.22 (6), P.115-118. (2005)

[11] An Aijun, Li Liang et al. Numerical Study on Depth of Post-Grouting in-situ of Length Bored Pile. Journal of Railway Science and Engineering. Vol. (8)2, P.53-58. (2011). 